\title{
Thoughts on Full-time Postgraduate Veterinary Talents Training in Local Agricultural Universities
}

\author{
Shuming Liu, ${ }^{1,}$, Lili Guan ${ }^{2, b}$, Aidong Qian ${ }^{1, \mathrm{c}}$ and Hongxia Ma $\mathrm{M}^{1, \mathrm{~d}^{\star}}$ \\ ${ }^{1}$ College of Animal Science and Technology, Jilin Agricultural University, Changchun 130118, China \\ ${ }^{2}$ College of Life Science, Jilin Agricultural University, Changchun 130118, China \\ aliushuming0121@163.com, b32233603@qq.com, 'cqianaidong0115@163.com, \\ dhongxia0731001@163.com \\ The corresponding author
}

Keywords: Full-time; Veterinary; Talents training; Applied talents

\begin{abstract}
This paper is going to carry out a preliminary discussion on the cultivating system for full-time postgraduate veterinary from the perspectives of optimizing training plan, changing education methods, highlighting tutor selection as well as comprehensively regulating education process management based on the current condition. So, this paper aims at constructing a new fulltime postgraduate veterinary training system which adapts to the development momentum.
\end{abstract}

\section{Introduction}

China is a country with aquaculture power and its economic ratio is increasing these years. At the same time, vets play a crucial role in national serious and unexpected public health incidents such as Sars, avian influenza, foot and mouth disease prevention. We need applied talents with high quality to participate in animal disease control. However, there is a shortage of applied vets currently and in order to solve this problem, the professional degree in veterinary emerges. The postgraduate veterinary is a two-year degree, including animal medicine, animal quarantine, animal protection, animal production, veterinary law enforcement and management etc. and the goal is to cultivate high-level applied and inter-disciplinary talents ${ }^{[1-2]}$ to be engaged in veterinary resource management, technical supervision, market management and development, veterinary clinical work and modern veterinary business and management. What's more, they should be independent in dealing with animal disease diagnosis, prevention, quarantine and veterinary medicine plan, management and implementation. Even though the degree of veterinary has been offered for decades, it is still in an early stage comparing to developed countries like United States of America. The postgraduate degree and training system in developed countries such as America are robust with special characteristics, which are carried out to cultivate applied talents from the perspectives of student source selection, learning method, course selection, teaching, guidance and degree requirement etc. In China, the number of colleges qualified for enrolling full-time veterinary is increasing and the training system has been created with clear goals and the course setting is comprehensive, professional and practical. However, according to the requirement of high-level applied veterinaries, the current training system is far from perfect.

Jilin Agricultural University is one of the agricultural schools firstly obtained the qualification to offer veterinary degrees ${ }^{[3]}$. In 2009 , full-time postgraduate veterinary degree was open to enroll undergraduates and the training system has been formed after practice. In addition, clear training objectives have been created which are comprehensive, professional and practical. However, according to the needs of high-level applied talents, the current veterinary postgraduate education is not perfect.

This paper is going to carry out a preliminary discussion on the cultivating system for full-time postgraduate veterinary from the perspectives of optimizing training plan, changing education methods, highlighting tutor selection as well as comprehensively regulating education process 
management based on the current condition. It will adhere to the running philosophy of facing the market and three rural issues, and it aims to cultivating veterinary professionals with innovative and practical skill so as to construct a new full-time postgraduate veterinary training system which adapts to the development momentum.

\section{Optimize Training Plan and Course Setting to Adapt to Employment in the Future}

The veterinary degree is a two-year program and students have to finish professional courses and graduation project, among which half the year is about theoretical course work and half of the year is for graduation paper writing. Actually, it is less than one year for students to carry out clinic practice and students cannot have professional veterinary education, which is not the goal of the education. At the same time, the course setting reform should adapt to the employment in the future. By collecting the teaching philosophy, advantages, characteristics, courses setting, teaching contents, methods ${ }^{[4-8]}$ of foreign countries regarding veterinary postgraduate education from abroad and at home, we can carry out comparison and collect relevant teaching experience. Based on this, we can come up with teaching reform plans and discuss with relevant teachers, postgraduate students and domestic professionals to modify training plans and carry out course setting by referring to foreign experience. By taking Jilin Agricultural University as an example, the course setting should implement credit system, the total credit should be 34 and course learning is 26, degree course is 20 , and 8 for required course. What's more, we should implement multidisciplinary, wide range training method (see table 1) and conduct trial implementation for class 2012 and 2012 so as to improve their comprehensive quality and enable them to fully play their potential and well adapt to the society as well as serve the society.

Students are going to finish the taught course learning in the first semester, therefore, tutors have to help students establish a development goal and guide students to select courses beneficial to their occupational development. So, in terms of course setting, we should add more selective courses in order to satisfy different targets of students. For example, students who want to be engaged in animals disease treatment should attend core courses including Epizootiology, Veterinary Pathology, Domestic Animal Surgery and Operation. In addition, new courses should also be added so as to satisfy those who expect to be engaged in pet grooming and healthcare field.

Full-time postgraduate veterinary course should highlight the characteristics of practice and therefore, the course setting should focus on practical skills training to cultivate students' ability in terms of doing stuff and innovating. Moreover, the goal of experiment is to prove the theoretical knowledge based on practice and in the meanwhile cultivate students' ability in terms of observing, analyzing and solving problems. During the process of training full-time postgraduate vets, we have to add the ratio of experiment classes and help them to understand the theoretical knowledge as well as practical skills in terms of clinical pathology, anatomy, disease pathogens laboratory science based on practice and clinic. Based on this, students will be familiar with disease case and checking in order to carry out correct treatment and establish as well as fully understand the inner relation among etiopathogenesis, diangostic method, treatment and curative effect.

The full-time postgraduate veterinary degree is a two-year program and there are not enough practical education time. In addition, most colleges do not invest enough on practical bases. So far, Jilin agricultural University only provides 1 cow field base and deer farm for the vet program. Confined to distance and accommodation, the practice sector cannot be implemented well, which needs further improvement.

\section{Change Single Teaching Mode, Mobilize the Initiative of Students}

The instructors of full-time postgraduate degree are mostly academic tutors and sometimes they cannot understand its education methods, and they cannot clearly understand the characteristics. Therefore, it is difficult to fundamentally change the teaching methods. Usually, they just adopt academic teaching methods, yet they have to face the problems of carrying out theoretical education and practices. Postgraduate education does not have lots of academic hours and tutors always focus 
on points in terms of key disease, inflammation identification, disease seminar. What's more, they will also adopt micro-class and flipped class together with heuristical and interesting teaching methods and discussion to encourage students to demonstrate themselves and initiative their ability to think. So, they can fully combine theory, clinic practice, front thoughts and their own thoughts to improve clinical diagnostic ability ${ }^{[9]}$.

Table 1 Postgraduate course setting of Jilin Agricultural University

\begin{tabular}{|c|c|c|c|c|}
\hline \multicolumn{2}{|c|}{ Course Type } & Course Name & Hour & Credits \\
\hline \multirow[t]{9}{*}{ Degree Courses } & General course & $\begin{array}{l}\text { Theory and Practice of Socialism with Chinese } \\
\text { Characteristics }\end{array}$ & 36 & 2 \\
\hline & & English & 80 & 2 \\
\hline & Field: Core courses & Modern Veterinary Immunology & 48 & 3 \\
\hline & & Modern Veterinary Pharmacology & 48 & 3 \\
\hline & & Veterinary Clinical Diagnosis Technology & 32 & 2 \\
\hline & & Veterinary Biologics Science & 32 & 2 \\
\hline & & Blight Pathogen Testing Technology & 32 & 2 \\
\hline & & Prevention and Control of Animal Epidemics & 32 & 2 \\
\hline & & Veterinary Medicine & 32 & 2 \\
\hline \multirow{11}{*}{$\begin{array}{l}\text { Non-degree } \\
\text { course }\end{array}$} & Elective Courses & English for Academic Conference & 16 & 1 \\
\hline & & Appreciation of Western Culture & 16 & 1 \\
\hline & & Scientific Writing & 16 & 1 \\
\hline & & Second Foreign Language ( English ) & 32 & 2 \\
\hline & $\begin{array}{l}\text { Major Elective } \\
\text { Courses }\end{array}$ & Modern Veterinary Pathology & 32 & 2 \\
\hline & & Veterinary Public Health and Inspection Technology & 16 & 1 \\
\hline & & Epizootiology & 16 & 1 \\
\hline & & Veterinary Science and Surgery & 16 & 1 \\
\hline & & Veterinary Laws and Regulations & 16 & 1 \\
\hline & & Modern Animal microbiology & 16 & 1 \\
\hline & & $\begin{array}{l}\text { Introduction to Modern Veterinary Medicine } \\
\text { Development }\end{array}$ & 16 & 1 \\
\hline
\end{tabular}

\section{Focus on Tutor Selection, Comprehensively Regulate Teaching Process Management}

In order to guarantee the quality of veterinaries, we have to strictly control the sectors including tutor selection, opening speech, mid-term check, thesis proposal, paper submitting etc. Different from basic academic papers, they can be investigation report, applied basic research, plan and design, product development, case analysis and project management. The goal is to assess students' comprehensive ability to adopt theoretical ability to solve real problems. Therefore, the topic of papers should be from social practice or real problems occurring in reality, which should also be targeted at concrete technical application, service, supervision and service management or magnificent and valuable problems. Furthermore, the topics should have a clear meaning and applied functions. However, most of tutors still focus on the academic and innovation perspective, and it is not rare to see genetic expression, which is opposite to the training target and direction. To conclude, the academic dissertation should be closely related to reality and highlight application.

At the same time, we have to establish an independent education evaluation system for full-time postgraduate veterinary students and we will evaluate based on professional, practical features. In addition, we have to perfect the education quality feedback system, including the suggestions from students in terms of education quality; moreover, we can refer to the experience of students after doing practice, teachers' response of course setting and education quality; furthermore, we should also take into consideration of instructors' guidance and suggestions for management ${ }^{[10]}$. Based on feedback, we will be familiar with the education condition of full-time postgraduate veterinary so as to continually improve education quality.

In addition, we should adopt double tutorial system, which is beneficial to cultivate independent 
talents to deal with vet technology service, management, project plan and implementation. Therefore, when postgraduates clear their development targets, internal tutors should help them contact external instructors and they should be granted senior title or they should be professional personnel with academic records. In addition, they should guide students to adapt to the work environment as early as possible and provide them with employment information so as to help them with career plan. Therefore, schools should give them rewards and help them raise prestige with preferential policies to guarantee the number and quality.

\section{Acknowledgements}

This research was supported by the School-level research topic of Jilin Agricultural University (Grant No.2015xjyb02) and Academic Postgraduate Course Construction of Jilin Agricultural University

\section{References}

[1] Ministry of Education, Opinions on How to Well Implement the Work of Full-time Postgraduate Veterinary Major . Teaching 2009. (In Chinese)

[2] D.Z Guo, G.F Cheng, D.R Bi, D. H Zhou and J.K Li, Preliminary Study on Training System for Full-time Postgraduate Veterinary,Vol.5(2011),p. 135-138. (In Chinese)

[3] H.Z Jiang, Y.F Sun, S.M Liu and Y.J Lou, A Preliminary Study on the Full-time Postgraduate Program Regarding Breeding Agriculture Provided by Local Agricultural Universities. Animal Husbandry and Feed Science, Vol. 34(2013)No. 10, p. 58-60. (In Chinese)

[4] J.C Tu, M.J Li, F.L Qin and H Wang, The Training Mode and Enlightenment of Agricultural Programs Provided by America, Journal of Anhui Agricultural Science, Vol. 35(2007)No.19, p. 5969-5971. (In Chinese)

[5] D.B Sun, J.F Wang, D.H Guo R Wu and D.Y Li, Exploration and Thoughts on the Training Mode of Full-time Postgraduate Veterinary Program in the Context of Practice, Animal Husbandry and Feed Science, Vol. 36(2015)No.2, p. 87-89. (In Chinese)

[6] X.E Ma, P.F Li, X.H Ding and Y Zhang, Thoughts on Strengthening the Cultivation of Veterinary Postgraduates, Journal of Inner Mongolia Agricultural University( Social Science Edition), Vol.4(2015)No.7, p. 104-106. (In Chinese)

[7] Y.F Li, M Song, L Gao, J.L Li, Z.G Zhang, Discussion on the Training Mode for Full-time Postgraduate Veterinaries, Education and Teaching Forum, Vol.1(2015)No.2, p. 150-151. (In Chinese)

[8] Q.Y Gao, Thoughts on the Training Mode for Postgraduate Veterinaries, Journal of Southwest Agricultural University (Social Science Edition), Vol.9(2011)No.8, p. 237-239. (In Chinese)

[9] R.F Cao, Suggestions to Cultivate Full-time Postgraduate Veterinary, Education Theory Research, Vol. 13(2015), p. 104-105. (In Chinese)

[10] Y.Q Ma, Thoughts on Cultivating Postgraduate Veterinaries, Higher Education, Vol.10(2011), p. 20-21. (In Chinese) 